\title{
Possibilities of prediction of service life of forming tools
}

Jiří Hrubý, Josef Rentka, Vladimíra Schindlerová, Lucie Krejčí, Xenie Ševčíková

Faculty of Mechanical Engineering, VŠB-Technical University Ostrava. Email: jiri.hruby@vsb.cz

The paper deals with stress of forming dies in complex conditions of concrete processes during their service life. Possibilities of assessment and prediction of tool service life based on comparative analysis of dynamic fatigue and abrasive wear are presented. Classical solution of dynamic fatigue is complemented by analysis of the situation of cyclic contact of rotating instruments. In this case super-position of cyclic pressure effect dominates, as well as abrasion on the surface of the functional surfaces of the rotating forming tool. Specific in this case is the different speed in the contact line and also the dynamics of development of size, shape and localisation of the surface exposed to wear by cyclic compressive stress. The solution is demonstrated on examples of different forms of wear of forging and rolling tools. The results of a comprehensive predictive analysis can be applied at designing of technological chains of forming operations.

Key words: estimation of tool service life, analysis of dynamic fatigue, abrasive wear, contact pressure

\section{References}

[1] FU, M. W., SHANG, B. Z. Stress analysis of the precision forging dies for a bevel gear and its optimal design using the boundary element method. J. Mater. Process. Technol., 1995, Vol. 53, pp. 511-520, ISSN 0924-0136.

[2] NĚMEC, J. Tuhost a pevnost ocelových součástí. Praha: Nakladatelství Československé akademie věd 1963. $2^{\text {nd }}$ ed. $771 \mathrm{pp}$.

[3] PETRUŽELKA, J., HRUBÝ, J., CARBOL, P. Analýza životnosti tvářecích nástrojů. In: Sborník přednášek 5. mezinárodní konference Nástroje ITC 2006. Zlín: Univerzita Tomáše Bati ve Zlíně, Fakulta technologická, Ústav výrobního inženýrství, 2006, p. 1-12 (CDROM), ISBN 80-7318-448-6.

[4] ASM Handbook, Vol. 19, Fatigue and fraction. ASM International. 1996. Product Code 06197G. ISBN 0-87170385-8, $341 \mathrm{p}$.

[5] ESPER, F. J., SONSONIO, C. M., Fatigue Design for PM Components. European Powder Metallurgy Association. Shrewsbury, UK 1997.

[6] BANNANTINE, J. A. et al. Fundamentals of Metal Fatigue Analysis. New Jersey: Prentice Hall 1990.

[7] BIBA, N., STEBUNOV, S., MUNTINGA, H. Increasing of Tool Life in Cold Forging by Means of FEM Simulation. In: International Conference «New Developments in Forging Technology» in Fillbach, Germany, 2005, ISBN 3-88355-342-5.

[8] GROENBAEK, J., BIRKER, T. Innovations in cold forging die design. J. Mater. Process. Technol., 2000 , Vol. 98, Issue 2, pp 155-161, ISSN 0924-0136.

[9] KNOERR, M., LANGE, K., ALTAN, T. Fatigue failure of cold forging tooling: causes and possible solutions through fatigue analysis. J. Mater. Process. Technol., 1994, Vol. 46, Issue 1-2, pp 57-71, ISSN 0924-0136.

[10] FALK, B., ENGEL, U., GEIGER, M. Estimation of tool life in bulk metal forming based on different failure concepts. J. Mater. Process. Technol., 1998, Vol. 80-81, pp 602-607, ISSN 0924-0136.

[11] LEE, G.-A., IM, Y.-T. Finite-element investigation of the wear and elastic deformation of dies in metal forming. J. Mater. Process. Technol., 1999, Vol. 89-90, pp 123-127, ISSN 0924-0136.

[12] LEE, Y. Ch., CHEN, F. K. Fatigue life of cold-forging dies with various values of hardness. J. Mater. Process. Technol., 2001, Vol. 113, pp 539-543, ISSN 0924-0136.

[13] SAROOSH, M. A., LEE, H.-C., IM, Y.-T., CHOI, S.-W., LEE, D.-L. High cycle fatigue life prediction of cold forging tools based on workpiece material property. J. Mater. Process. Technol., 2007, Vol. 191, pp 178-181, ISSN 0924-0136.

[14] LEE, H.-C., LEE, Y., LEE, S.-Y., CHOI, S., LEE D.-L. IM, Y.-T. Tool life prediction for the bolt forming process based on high-cycle fatigue and wear. J. Mater. Process. Technol., 2008, Vol. 201, pp 348-353, ISSN 0924-0136.

[15] JASIONOWSKI, R., PODREZ-RADZISZEWSKA, M., ZASADA, D. Cavitation erosion resistance of the chosen aluminium alloys. Manufacturing Technology, 2011, Vol. 11, No. 11, pp. 22-28, ISSN 1213-2489 
[16] ČUBAN, J., CALONIUS O., PIETOLA, M., JERSÁK J. Fatigue life and surface integrity measurements of EN S355J2 steel used in hydraulic components. Manufacturing Technology, 2011, Vol. 11, No. 11, pp. 5-11, ISSN 1213-2489.

[17] MÜLLER, M., VALÁŠEK, P. Interaction of steel surface treatment by means of abrasive cloth and adhesive bond strength. Manufacturing Technology, 2010, Vol. 10, pp. 49-57, ISSN 1213-2489. 